\title{
Culturing of Autoflocculating Microalgal Consortium in Continuous Raceway Pond Reactor
}

\author{
Chandrasekharan Nair Aneesh, Faisal Mullalayam, Vattackatt Balakrishnan Manilal, \\ Ajit Haridas* \\ Process Engineering and Environmental Technology Division, National Institute for Interdisciplinary Science and \\ Technology (NIIST-CSIR), Thiruvananthapuram, India \\ Email: ${ }^{*}$ ajitharidas@niist.res.in
}

Received 28 July2015; accepted 27 September 2015; published 30 September 2015

Copyright (C) 2015 by authors and Scientific Research Publishing Inc.

This work is licensed under the Creative Commons Attribution International License (CC BY).

http://creativecommons.org/licenses/by/4.0/

(c) (i) Open Access

\section{Abstract}

The goal of this study was to develop a self-settling microalgal consortium in raceway pond reactor (RPR). Experiments were carried out with cultures that developed without additional seeding, but naturally promoted by process conditions in a raceway pond reactor. The changes in microalgal communities and total biomass under nitrogen and phosphorous limitations were studied in both batch and continuous systems. At the steady state batch had the population of $46 \%$ Euglena sp., $16 \%$ Closterium sp., $14 \%$ Chlorella sp., 14\% Scenedesmus sp. and 10\% Ankistrodesmus sp. with a maximum biomass of $900 \mathrm{mg} / \mathrm{L}$. In order to get self-settling microalgal consortium, the operation was changed to continuous continuous mode with the aid of a specially designed settler for daily harvest and recycling of the biomass. Grazing fauna could be controlled by managing reduced liquid and solid retention time. At steady-state condition, an autofloculating and self-settling consortium was developed which had mainly Fragilaria sp., Scenedesmus sp., and filamentous Ulothrix sp. The maximum biomass concentration obtained was $140 \mathrm{mg} / \mathrm{L}$. The presence of neutral lipid droplets in the consortium was identified by staining with Nile Red. Development of the lipid rich consortium could be a suitable method for producing biofuel.

\section{Keywords}

Self-Settling, Microalgal Consortium, Raceway Pond Reactor, Autoflocculating

\footnotetext{
${ }^{*}$ Corresponding author.
}

How to cite this paper: Aneesh, C.N., Mullalayam, F., Manilal, V.B. and Haridas, A. (2015) Culturing of Autoflocculating Microalgal Consortium in Continuous Raceway Pond Reactor. American Journal of Plant Sciences, 6, 2472-2480. 


\section{Introduction}

Microalgae are the subject of extensive research today. The photosynthetic capacity and high growth rate are the attractive features of microalgae to consider them for biotechnology industries. More than a thousand species of microalgae have been reported from Indian waters which are useful for producing valuable metabolites. The range of products researched from microalgae includes protein, carbohydrates, lipids, carotenoids and vitamins. All these metabolites can be used as foods, feeds, high value bioactives and energy sources [1]-[5]. In fact, many species of microalgae are used as live feed in aquaculture firm. Microalgae are also useful in the area of wastewater treatment because of their efficiency in nitrogen and phosphorus removal.

Even though technologies for the conversion of microalgal biomass to various value added products have been established, many of them cannot be commercialized. Lack of suitable culture methods is the unfavorable part of the technologies. Enhanced biomass production is possible only through engineered aquaculture systems and it is essential for the economic viability. The promising methods of large scale production for microalgae are raceway ponds [6] [7] and tubular photo bioreactors [7]. Among these Raceway Pond Reactor (RPR) is considered as a suitable method to cultivate microalgae in large scale harnessing sunlight. Achieving the growth of desirable microalgae is usually difficult in open ponds. Economics of biomass production will be improved if the selected microalgae can be cultivated continuously without contamination in an open system [8] and harvested inexpensively.

The R\&D effort on microalgae has been focused substantially on two approaches so far: 1) collecting, culturing and cultivating natural algal strains that have high commercial application; and 2) engineering the genetics of algae to improve the biomass yield. This study presents the selection and culturing of microalgal consortium by providing an environmental pressure through engineering approaches in the RPR. This study further discusses the microalgal ecosystem of the RPR.

\section{Materials and Methods}

\subsection{Experimental Setup}

A raceway pond reactor was setup to grow algae naturally present in the source water. The water source was tap water, which is supplied from bank filtered river water of Karamana, Thiruvananthapuram. The RPR was operated in batch for 20 days by adding nutrients initially in a single dose. After promoting the growth of biomass, the raceway pond reactor was operated in continuous mode. Water was pumped into the RPR and the same amount of liquor was discharged through the outflow of a tube settler which is fabricated in the laboratory. The process flow diagram and tube settler are shown in Figure 1 and Figure 2 respectively. In the scheme a half part of the settled biomass from the settler was recycled to the RPR and the remaining fifty percent was harvested using a pump.

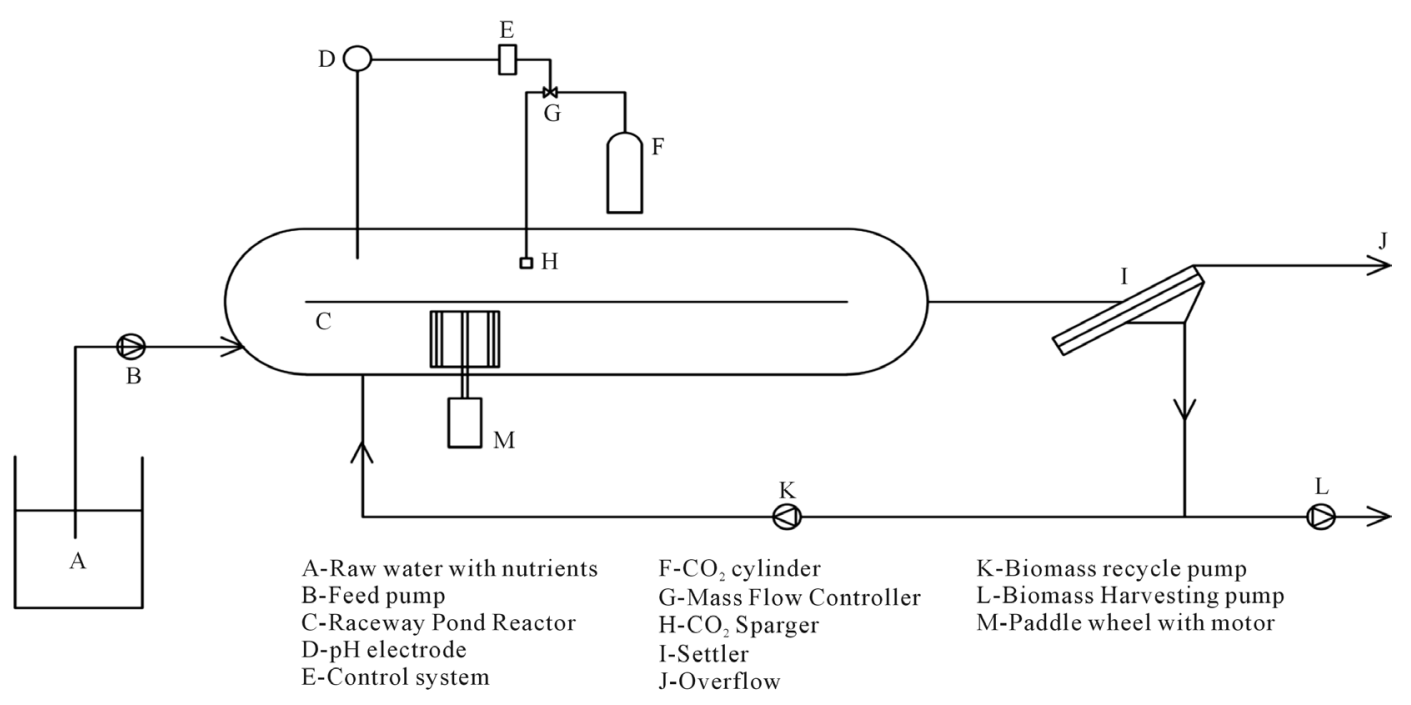

Figure 1. Process flow diagram of continuous raceway pond reactor (RPR). 


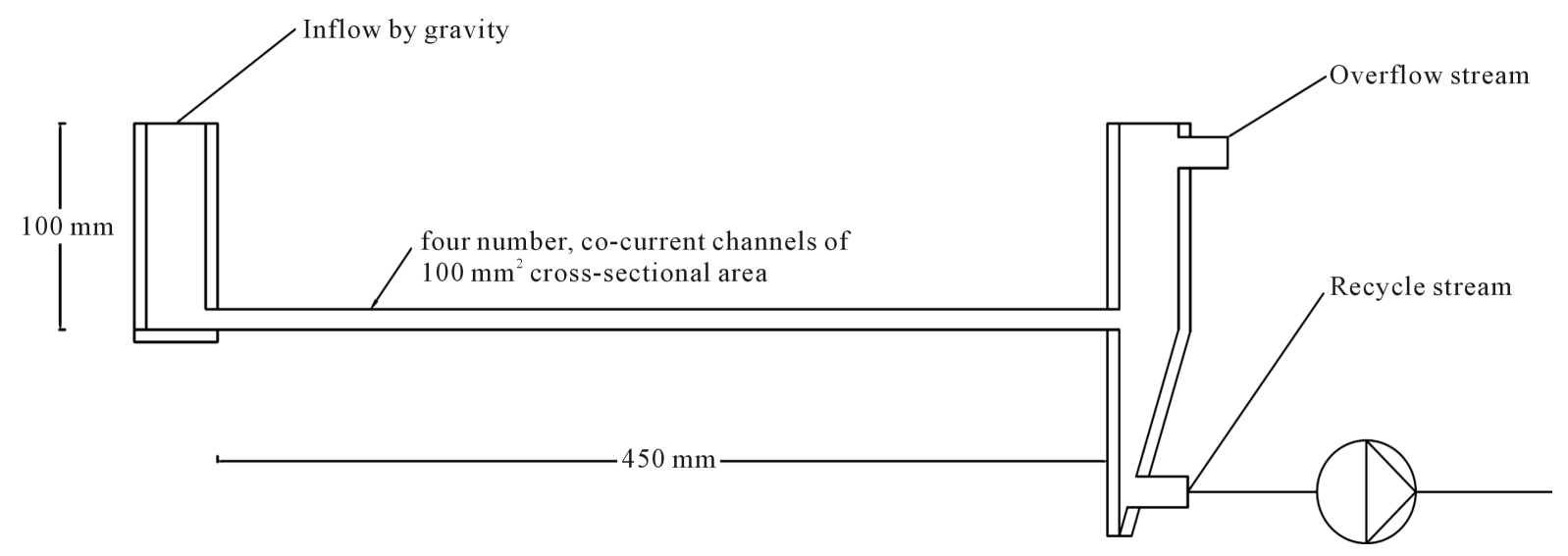

Figure 2. Scheme of the tube-settler connected to the RPR.

Dimensions of the experimental RPR were $1.0 \mathrm{~m}$ length, $0.35 \mathrm{~m}$ depth and $0.5 \mathrm{~m}$ width, and it had the working depth of $28 \mathrm{~cm}$. Working volume of the RPR was $210 \mathrm{~L}$ in both batch and continuous operations. The reactor was mounted above roof top and away from shadows. A minimum liquid circulation velocity for mixing was maintained in the RPR by the motion of a four paddled drive rotated at $6 \mathrm{rpm} . \mathrm{CO}_{2}$ was sparged into the pond through a fine bubble diffuser at the rate of $100 \mathrm{std}$. mL/minute to ensure unlimited availability of $\mathrm{CO}_{2}$ for photosynthesis [9].

A tube-settler was designed and fabricated for harvesting the algal biomass from RPR (Figure 2). Tube settlers are shallow settling devices used to enhance the settling characteristics of sedimentation basin. This settler allows settling of solids in short time because of the small depth. Particle that travels above the settling depth or unsettlable are removed from suspension through the overflow stream (Figure 2). This was made to select the fast settling microalgal biomass from natural consortium during the continuous operation of RPR. A periodic rapping mechanism was provided to dislodge sticky biomass on the walls of the tube-settler. The liquid retention time in tube was 30s.

\subsection{Batch Operation}

The composition of nutrients added at startup stage was: $\mathrm{NH}_{4} \mathrm{Cl}-20 \mathrm{~g}, \mathrm{KH}_{2} \mathrm{PO}_{4}-7.5 \mathrm{~g}, \mathrm{CaCl}_{2}-5 \mathrm{~g}, \mathrm{SrCl}_{2}-5$ g, $\mathrm{CdCl}_{2} \cdot 2 \mathrm{H}_{2} \mathrm{O}-2.5 \mathrm{~g}, \mathrm{Na}_{2} \mathrm{SO}_{4}-20 \mathrm{mg}, \mathrm{MgSO}_{4} \cdot 7 \mathrm{H}_{2} \mathrm{O}-1 \mathrm{mg}$ and with $40 \mathrm{~mL}$ trace metals from the stock solution of $\mathrm{FeCl}_{3}-2000 \mathrm{mg}, \mathrm{MnCl}_{2} \cdot 2 \mathrm{H}_{2} \mathrm{O}-500 \mathrm{mg}, \mathrm{ZnCl}_{2}-50 \mathrm{mg}, \mathrm{NH}_{4} \mathrm{Mo}_{7} \mathrm{O}_{24} \cdot 4 \mathrm{H}_{2} \mathrm{O}-50 \mathrm{mg}, \mathrm{CoCl}_{2} \cdot 6 \mathrm{H}_{2} \mathrm{O}-50$ $\mathrm{mg}, \mathrm{CuCl}_{2} \cdot 2 \mathrm{H}_{2} \mathrm{O}-50 \mathrm{mg}, \mathrm{EDTA}-500 \mathrm{mg}, \mathrm{NaSeO}_{3}-100 \mathrm{mg}, \mathrm{H}_{3} \mathrm{BO}_{3}-50 \mathrm{mg}, \mathrm{AlCl}_{3}-50 \mathrm{mg}, \mathrm{HCl}-1 \mathrm{~mL}$. This composition was based upon the elemental stoichiometry studies of microalgal species developed by Ho et al. [10]. The RPR was started with the algal population naturally present in the water source and continued the experiment for 20 days. The biomass collected from the suspension was undergone for detailed examinations.

\subsection{Continuous Operation}

Batch operation of the RPR was made continuous by supplying nutrients daily as a pulse at $10 \%$ of the quantity supplied initially to the batch RPR system. The tube-settler as referred previously was fitted to the outflow of RPR during the continuous operation. Water was pumped into the RPR every day at the rate of 25 liters per hour from 14:00 Hrs to 18:00 Hrs. To select self-settling microalgal consortium in the reactor about 50\% of the settled biomass sludge from the settler was pumped back into the RPR. Thus the biomass retention time in the reactor was two days. This biomass retention time was selected to washout metazoan grazers which feed on microalgae. Upon forming a stable consortium after 14 days, the daily addition of nutrients was doubled to yield higher biomass.

\subsection{Physico-Chemical and Biological Analysis}

Volume of the settled biomass was measured using a graduated 1 L Imhoff cone [11]. Residual-ammonia and orthophosphates were estimated by spectroscope, as per APHA [11]. The growth of microalgal population was 
monitored in terms of total suspended solids [11]. Identification and enumeration of microalgae and grazing organisms present in the RPR were done based on the morphological characteristics illustrated in the previous literature with the aid of a Sedgewick-Rafter (SR) counting chamber and an optical microscope [11] [12].

\subsection{Qualitative Lipid Content Estimation}

Qualitative assessment of lipid was done by staining with Nile Red (NR) [13]. NR is a lipophilic fluorescent dye used for intracellular lipid determination in prokaryotic and eukaryotic cells and capable of detecting neutral lipids. NR permeates all structures within the cell but the yellow-gold fluorescence manifests when NR penetrates intracellular neutral lipid globules. Stock solution of the stain was prepared by dissolving $10 \mathrm{mg}$ of Nile Red in $1 \mathrm{~mL}$ of acetone and the working standard was prepared with of $10 \mu \mathrm{L}$ stock solutions made up to $1 \mathrm{~mL}$ with acetone. Then $0.5 \mathrm{~mL}$ of microalgal cells was collected by centrifugation at $1500 \mathrm{rpm}$ for 10 minutes. The cells were washed in $0.5 \mathrm{~mL}$ of physiological saline solution $(0.85 \% \mathrm{NaCl}$ solution in water) and resuspended the collected cells in $0.5 \mathrm{~mL}$ of physiological solution. Nile Red solution $(0.1 \mathrm{mg} / \mathrm{mL}$ acetone) was added to the suspension and incubated for 10 minutes. After washing once stained microalgal cells were observed under fluorescent microscope. Lipid droplets were observed as bright yellow-red fluorescence with Y3 filter in epifluorescent microscope (Leica DM-2500). Cyanobacteria also had auto-fluorescence under the same excitation, but it could be distinguished from Nile Red stained lipid droplets by difference in colour shade.

\section{Results}

\subsection{Batch RPR Ecosystem}

The nutrients enriched batch RPR had initially the dominant growth of a single celled Chlorella of the size 2 $10 \mu \mathrm{m}$ with the cell concentration of around $9 \times 10^{3}$ cells/mL. This Chlorella growth was then replaced by a microalgal community of $46 \%$ Euglena sp., $16 \%$ Closterium sp., 14\% Chlorella sp., $14 \%$ Scenedesmus sp. and 10\% Ankistrodesmus sp. within 10 days and the total biomass concentration was $900 \mathrm{mg} / \mathrm{L}$. The growth of photosynthetic biomass was not only in suspended form in water but as attached on the light and water available side walls of the reactor and on the paddle wheels also. Over the period of 15 days ammonia and phosphate concentration were depleted to $0.01 \mathrm{mg} / \mathrm{L}$ from their initial concentrations of $30 \mathrm{mg} / \mathrm{L}$ and $24 \mathrm{mg} / \mathrm{L}$ respectively. The diurnal changes in $\mathrm{pH}$ were in the range of 6.5 to 7.8 from the initial value of 7.0. By the end of 20 days of batch experiment Chlamydomonas sp. was observed mainly as zygospores. Grazers such as protozoa, rotifers, and Chironomous fly larvae were found to appear in the RPR towards the end of the batch experiment (Table 1 and Figure 3).

Microscopic observation revealed that grazers like rotifers, Vorticella, Carchesium colonies found in the system were consuming the suspended organisms like bacteria and microalgae present in the RPR. Rotifers were free living organisms in the RPR and actively grazed on microalgal species such as Chlorella. Each cell of Vorticella has a separate stalk anchored to the microalgal consortium floc and actively fed on organisms present in the suspension. In batch system the grazing organisms were feeding the cells in the suspension.

Table 1. Account of grazers in the batch RPR system over the period of 20 days.

\begin{tabular}{cc}
\hline Grazers & No. of cells $/ \mathrm{mL}$ \\
\hline Vorticella & 6 \\
Carchesium & 3 \\
Colpoda & 2 \\
Rotifers & 4 \\
Oxytricha & 1 \\
Chironomous larvae & 0.066 \\
\hline
\end{tabular}





Figure 3. Bright field micrographs of grazers in the batch RPR system appeared over the period of 20 days. (a) Carchesium colony attached to a microalgal consortium floc (20x); (b) Rotifer and Vorticella (40x); (c) Oxytricha, a ciliate protozoan (40x).

\subsection{Continuous RPR Ecosystem}

The organisms present in the beginning of continuous culture were Chlamydomonas sp., Euglena sp., Ankistrodesmus sp., Closterium sp. and Scenedesmus sp. In continuous RPR with the initial nutrient concentration, the average biomass concentration was $65 \mathrm{mg} / \mathrm{L} /$ day. To get a steady state of biomass production, initially $25 \%$ of the biomass was harvested daily. On reaching the steady state, the Euglena sp. (Figure 4(a)) disappeared and the biomass was dominated by Closterium sp. (Figure 4(b)). After 14 days with doubling of nutrients loading from the initial concentration the total biomass level increased to $140 \mathrm{mg} / \mathrm{L} /$ day, with the same harvesting frequency. Under these conditions, there was a shift in the composition of the consortium. It was dominated by diatoms and green algae (Scenedesmus sp., filamentous Ulothrix sp. (Figure 4(c), Figure 4(d) and Figure 4(e)). The settler aided operation could select flocculant and self-settling consortium in the RPR. A mucilaginous cover was present around the floc. The settled biomass was $2 \mathrm{ml} / \mathrm{L}$ in an Imhoff cone which was taken for settling experiment and allowed to settle for 1 minute. The supernatant was essentially free of suspended microalgal cells. The steady state floc was dominated by filamentous diatom Fragilaria sp. (Figure 5) and filamentous Ulothrix sp. Lipid droplets were observed in both by staining with Nile Red (Figure 6(a) and Figure 6(b)). Lipid is seen as bright yellow in filamentous Fragilaria, and as reddish fluorescence in filamentous Ulothrix. The
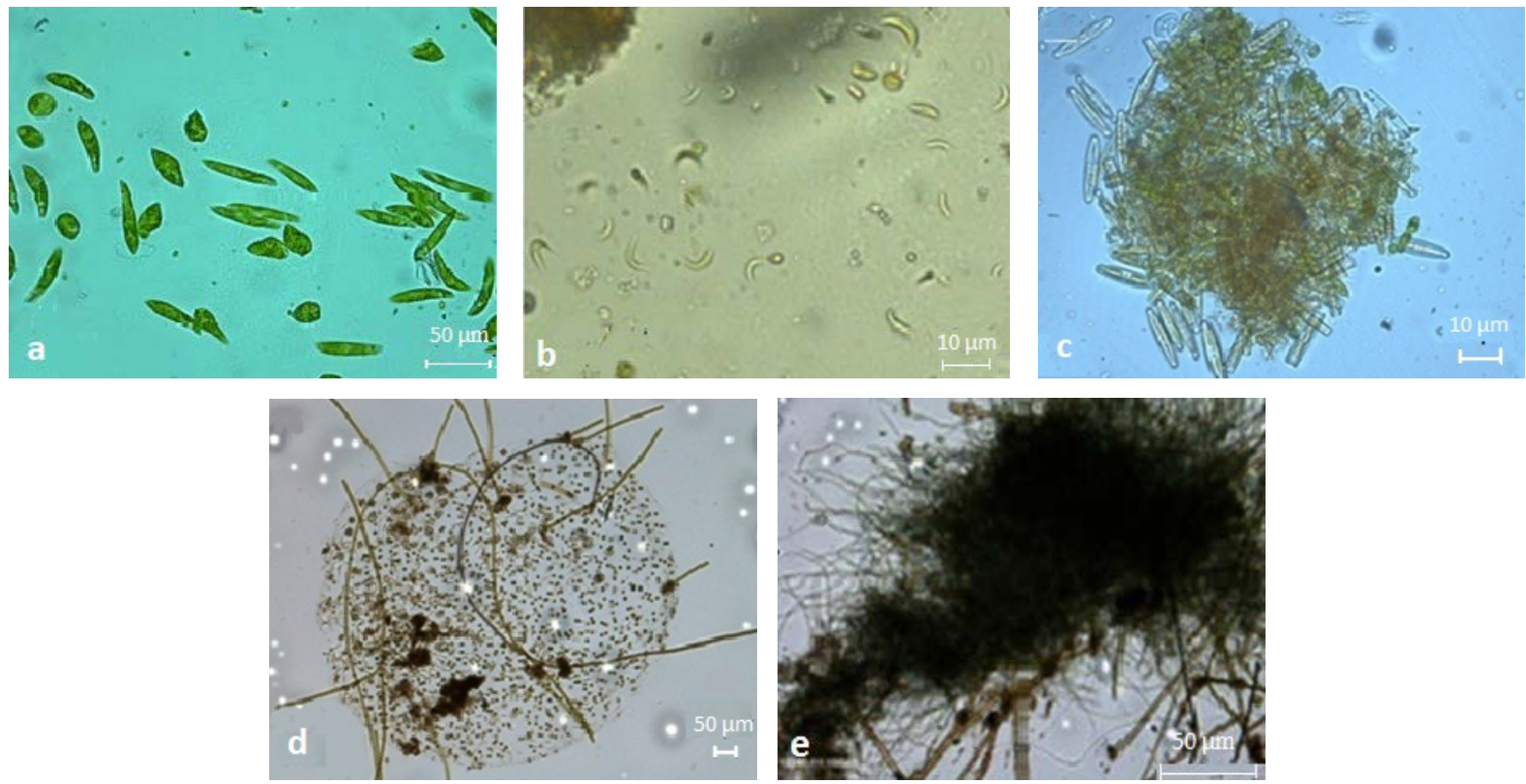

Figure 4. Microscopic images of microalgae present in the continuous RPR system. (a) Euglena sp. dominant starter culture from batch reactor; (b) Closterium sp. dominance in continuous system; (c) Bright-field micrographs of self settling flocs; (d) Stereo micrographs of self settling flocs (1x); (e) Stereo micrographs of self settling flocs (10x). 

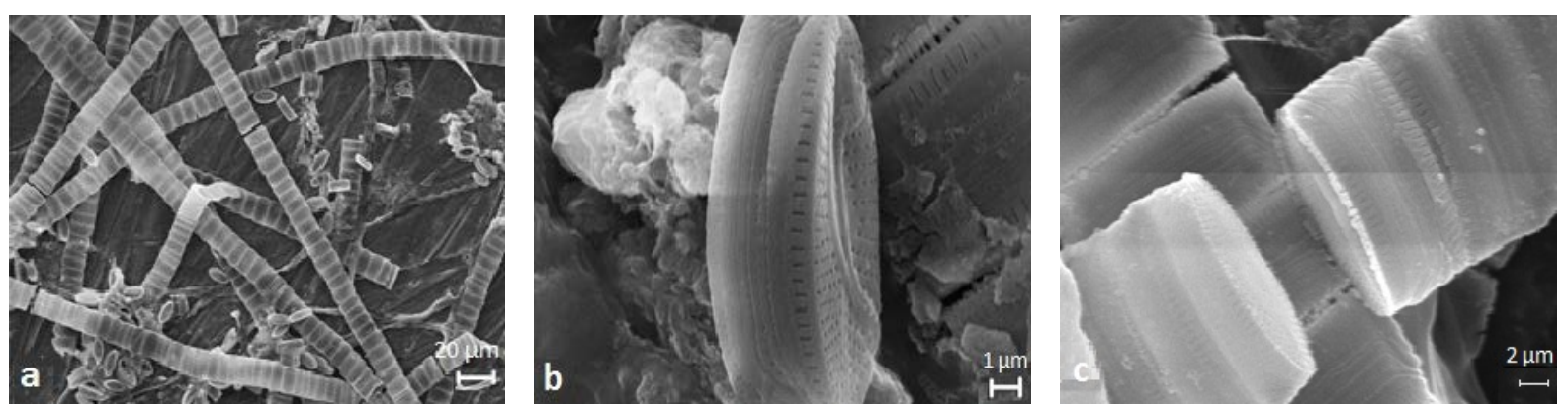

Figure 5. Scanning electron micrographs of Fragilaria sp. in the self-settling consortium. (a) Scanning electron micrographs of filamentous Fragilaria sp. (1 kx); (b) Scanning electron micrographs of a single cell of Fragilaria sp. (17 kx); Scanning electron micrographs of broken filaments of Fragilaria sp. (9.85 kx).
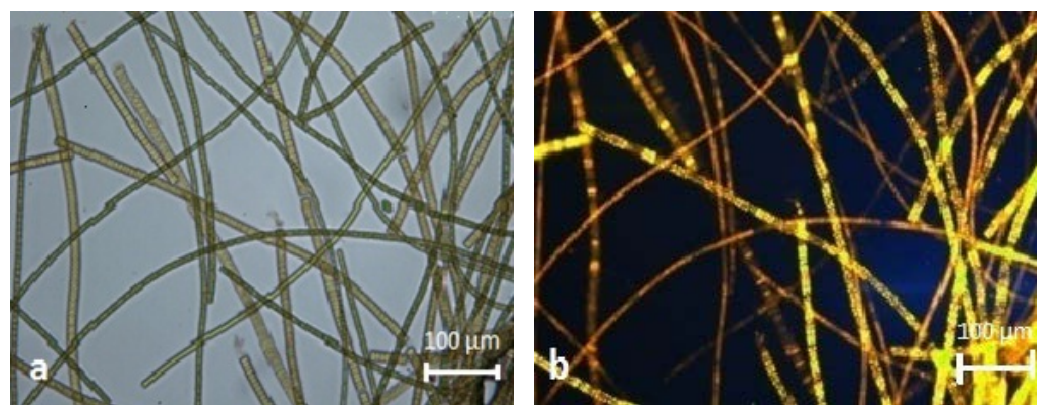

Figure 6. Nile Red stained microscopic images of flocs in continuous RPR system. (a) Nile Red stained floc seen through bright field microscope (10x); (b) Nile Red stained floc seen through epifluorescence with y3 filter cube (10x).

reddish color is the result of fluorescence of lipid droplets located in the cytoplasm seen through green pigmented chloroplast on the outer cell surface.

\section{Discussion}

In this effort to develop self-settling microalgal consortium experiments were performed to promote the growth of microalgae originally present in the sample water. The addition of nutrients as an initial dose triggered the growth of Chlorella in 24 hrs. Rapid growth of Chlorella and its tolerance to ammonia concentration near to a level of $30 \mathrm{mg} / \mathrm{L}$ have been reported earlier [14] [15]. It is reported that Chlorella sp. are highly competitive when the concentration of $\mathrm{NH}_{3}-\mathrm{N}$ concentration is between $20-250 \mathrm{mg} / \mathrm{L}$ [16]. The other microalgae started to appear when supplied nutrients became very low and depleted to below detection limit. In this batch system the biomass concentration was $900 \mathrm{mg} / \mathrm{L}$. There was flocculation of the microalgal consortium in the culture and the suspended single cells were grazed and removed. Towards the end of the batch culturing in RPR Chlamydomonas was the dominant one and mainly observed as zygospores where the nitrogen in the RPR was less than detectable range of $0.01 \mathrm{mg} / \mathrm{L}$. The zygosporic formation of Chlamydomonas under nitrogen limited condition has also been reported previously as well [17] [18].

The continuous operation of RPR with biomass settler for biomass recycles and harvest changed the microbial ecology of the RPR. Settler operation selected the settlable biomass and washed out the suspended cells slowly from the reactor. Continued operation of the RPR converged the consortium to mainly two members from its original diverse population. The biomass grown in the batch RPR was not easily separable as there were discrete and suspended cells in the culture (Table 2). While in the continuous operation of RPR with settler the biomass was entirely in the form of easily settleable flocs because of the recycle of settled biomass and washing out of the suspended growth.

It was observed that the process of settleable biomass developments through hydrodynamic selection is qualitatively different from the method of formation of settling biomass in the batch system. In continuous RPR system settled flocs were up to $1 \mathrm{~mm}$ diameter and non settled flocs were in the range of $0.1-0.2 \mathrm{~mm}$ diameter. 
Table 2. Proportion of settled and non-settled microalgae in tube-settler.

\begin{tabular}{cccc}
\hline Name of Species & $\begin{array}{c}\text { Total Number of Microalgae } \\
\text { in the Sample (Cells/mL) }\end{array}$ & $\begin{array}{c}\text { Total Number of Settled } \\
\text { Microalgae (Cells/mL) }\end{array}$ & $\begin{array}{c}\text { Total Number of Microalgae in the } \\
\text { Overflow from Settler (Cells/mL) }\end{array}$ \\
\hline Euglena sp. & $30.6 \times 10^{3}$ & $17.6 \times 10^{3}$ & $13 \times 10^{3}$ \\
Closterium sp. & $10.4 \times 10^{3}$ & $9.6 \times 10^{3}$ & $0.8 \times 10^{3}$ \\
Scenedesmus sp. & $8.8 \times 10^{3}$ & $5 \times 10^{3}$ & $3.8 \times 10^{3}$ \\
Ankistrodesmus sp. & $6.4 \times 10^{3}$ & $4.8 \times 10^{3}$ & $1.6 \times 10^{3}$ \\
Chlorella sp. & $9.4 \times 10^{3}$ & $6.2 \times 10^{3}$ & $3.2 \times 10^{3}$ \\
\hline
\end{tabular}


Figure 7. Mucilagenous secretions found in flocs of batch RPR system. (a) Stereo micrograph of spherical shaped floc, cells are bound by the mucilage produced by the organisms; (b) Bright field images of mucilagenous floc; (c) Phase contrast images of mucilagenous floc.

The non-settled flocs show tendency to separate and are washed out of the system through hydrodynamic selection pressure. On the other hand in the batch system, flocs are formed by the active production of exocellular materials seen as mucilage in the floc (Figure 7) and most of the individual cells get attached to this mucilaginous substance for some kind of biological association. Cell division can take place within this mucilage floc, thereby restricting separation of the cells. Grazing organisms present in the batch system remove free suspended cells in the system [19] [20]. Small grazers, such as ciliates and rotifers, are unable to penetrate the mucilaginous cover of the floc for feeding on the cells. Flocs are grazed mainly by metazoans such as nematodes and insect larvae.

Growth of diatoms was observed without addition of silica along with other nutrients, probably by utilizing dissolved silica present in the range of $12 \mathrm{mg} \mathrm{SiO} / \mathrm{L}$ to $15 \mathrm{mg} \mathrm{SiO} / / \mathrm{L}$. Lipid is the primary energy storage product of diatom and usually have higher growth rate than green algae [21]-[23]. Lipid production in diatoms has been reported to increase in silica limiting condition [21] [22] [24] [25]. Conditions of nitrogen starvation and nitrogen limitation are also known to cause lipid accumulation in several microalgal species [15] [26] [27]. The presence of lipid droplets in the consortium could be due to the above stated reasons.

\section{Conclusion}

This study demonstrated the flocculant and settleable microalgal consortium growth in continuous raceway pond reactor with the aid of a tube settler. The developed consortium was stable and perpetual as far as the process conditions remained unchanged. Fast growth rate with lipid accumulation and seperability from aqueous phase was the main characteristics of the consortium. Further studies were required to improve the biomass and lipid productivity of the consortium.

\section{Acknowledgements}

This research work is funded through CSIR-NMITLI project "biofuel from marine microalgae". The following contributions are also acknowledged: Betsy A. Chacko for examination and enumeration of metazoans; Ujjal Mondal for analysis of silica in water, uptake of silica, settling tests and biomass filterability studies; Farza 
Naushad and Geethu: development and analysis of lipid content in biomass; G.S. Godwin for operation and maintenance of raceway pond.

\section{References}

[1] Shimizu, Y. (1996) Microalgal Metabolites: A New Perspective. Annual Reviews in Microbiology, 50, 431-465. http://dx.doi.org/10.1146/annurev.micro.50.1.431

[2] Akkerman, I., Janssen, M., Rocha, J. and Wijffels, R.H. (2002) Photobiological Hydrogen Production: Photochemical Efficiency and Bioreactor Design. International Journal of Hydrogen Energy, 27, 1195-1208. http://dx.doi.org/10.1016/S0360-3199(02)00071-X

[3] Singh, A. and Ward, O. (2005) Microbiology of Bioreactors for Waste Gas Treatment. Springer, Berlin Heidelberg, 101-121. http://dx.doi.org/10.1007/3-540-27007-8_5

[4] Walker, T.L., Purton, S., Becker, D.K. and Collet, C. (2005) Microalgae as Bioreactors. Plant Cell Reports, 24, 629641. http://dx.doi.org/10.1007/s00299-005-0004-6

[5] Spolaore, P., Joannis-Cassan, C., Duran, E. and Isambert, A. (2006) Commercial Applications of Microalgae. Journal of Bioscience and Bioengineering, 101, 87-96. http://dx.doi.org/10.1263/jbb.101.87

[6] Terry, K.L. and Raymond, L.P. (1985) System Design for the Autotrophic Production of Microalgae. Enzyme and Microbial Technology, 7, 474-487. http://dx.doi.org/10.1016/0141-0229(85)90148-6

[7] Molina Grima, E., Fernández, F.G.A., García Camacho, F. and Chisti, Y. (1999) Photobioreactors: Light Regime, Mass Transfer, and Scaleup. Journal of Biotechnology, 70, 231-247. http://dx.doi.org/10.1016/S0168-1656(99)00078-4

[8] Borowitzka, M. (2005) Culturing Microalgae in Outdoor Ponds. Algal Culturing Techniques, 205-218. http://dx.doi.org/10.1016/b978-012088426-1/50015-9

[9] Olaizola, M., Duerr, E. and Freeman, D. (1991) Effect of $\mathrm{CO}_{2}$ Enhancement in an Outdoor Algal Production System Using Tetraselmis. Journal of Applied Phycology, 3, 363-366. http://dx.doi.org/10.1007/BF02392890

[10] Ho, T.-Y., Quigg, A., Finkel, Z.V., Milligan, A.J., Wyman, K., Falkowski, P.G. and Morel, F.M.M. (2003) The Elemental Composition of Some Marine Phytoplankton. Journal of Phycology, 39, 1145-1159. http://dx.doi.org/10.1111/j.0022-3646.2003.03-090.x

[11] APHA (1998) Standard Methods for the Examination of Water and Wastewater. 20th Edition, American Public Health Association, New York.

[12] Davis, C.C. (1955) The Marine and Fresh-Water Plankton. Michigan State University Press, East Lansing.

[13] Cooksey, K.E., Guckert, J.B., Williams, S.A. and Callis, P.R. (1987) Fluorometric Determination of the Neutral Lipid Content of Microalgal Cells Using Nile Red. Journal of Microbiological Methods, 6, 333-345. http://dx.doi.org/10.1016/0167-7012(87)90019-4

[14] de-Bashan, L.E., Trejo, A., Huss, V.A., Hernandez, J.-P. and Bashan, Y. (2008) Chlorella sorokiniana UTEX 2805, a Heat and Intense, Sunlight-Tolerant Microalga with Potential for Removing Ammonium from Wastewater. Bioresource Technology, 99, 4980-4989. http://dx.doi.org/10.1016/j.biortech.2007.09.065

[15] Li, Y., Horsman, M., Wang, B., Wu, N. and Lan, C.Q. (2008) Effects of Nitrogen Sources on Cell Growth and Lipid Accumulation of Green Alga Neochloris oleoabundans. Applied Microbiology and Biotechnology, 81, 629-636. http://dx.doi.org/10.1007/s00253-008-1681-1

[16] Wong, M., Hung, K. and Chiu, S. (1996) Sludge-Grown Algae for Culturing Aquatic Organisms: Part II. SludgeGrown Algae as Feeds for Aquatic Organisms. Environmental Management, 20, 375-384. http://dx.doi.org/10.1007/BF01203845

[17] Harris, G. (2012) Phytoplankton Ecology: Structure, Function and Fluctuation. Springer Science \& Business Media, Amesterdam.

[18] Trainor, F.R. (1970) Survival of Algae in a Desiccated Soil. Phycologia, 9, 111-113. http://dx.doi.org/10.2216/i0031-8884-9-2-111.1

[19] Lurling, M. and Beekman, W. (2006) Palmelloids Formation in Chlamydomonas reinhardtii: Defence against Rotifer Predators? Annales de Limnologie - International Journal of Limnology, 42, 65-72.

[20] Jezberová, J. and Komárková, J. (2007) Morphological Transformation in a Freshwater Cyanobium sp. Induced by Grazers. Environmental Microbiology, 9, 1858-1862. http://dx.doi.org/10.1111/j.1462-2920.2007.01311.x

[21] McGinnis, K.M., Dempster, T.A. and Sommerfeld, M.R. (1997) Characterization of the Growth and Lipid Content of the Diatom Chaetoceros muelleri. Journal of Applied Phycology, 9, 19-24.

http://dx.doi.org/10.1023/A:1007972214462

[22] Hu, Q., Sommerfeld, M., Jarvis, E., Ghirardi, M., Posewitz, M., Seibert, M. and Darzins, A. (2008) Microalgal Tria- 
cylglycerols as Feedstocks for Biofuel Production: Perspectives and Advances. The Plant Journal, 54, 621-639. http://dx.doi.org/10.1111/j.1365-313X.2008.03492.x

[23] Chaffin, J., Mishra, S., Kuhaneck, R., Heckathorn, S. and Bridgeman, T. (2012) Environmental Controls on Growth and Lipid Content for the Freshwater Diatom, Fragilaria capucina: A Candidate for Biofuel Production. Journal of Applied Phycology, 24, 1045-1051. http://dx.doi.org/10.1007/s10811-011-9732-x

[24] Coombs, J., Halicki, P.J., Holm-Hansen, O. and Volcani, B.E. (1967) Studies on the Biochemistry and Fine Structure of Silica Shell Formation in Diatoms: II. Changes in Concentration of Nucleoside Triphosphates in Silicon-Starvation Synchrony of Navicula pelliculosa (Bréb.) Hilse. Experimental Cell Research, 47, 315-328. http://dx.doi.org/10.1016/0014-4827(67)90234-0

[25] Chelf, P. (1990) Environmental Control of Lipid and Biomass Production in Two Diatom Species. Journal of Applied Phycology, 2, 121-129. http://dx.doi.org/10.1007/BF00023373

[26] Griffiths, M.J. and Harrison, S.T. (2009) Lipid Productivity as a Key Characteristic for Choosing Algal Species for Biodiesel Production. Journal of Applied Phycology, 21, 493-507. http://dx.doi.org/10.1007/s10811-008-9392-7

[27] Rodolfi, L., Chini Zittelli, G., Bassi, N., Padovani, G., Biondi, N., Bonini, G. and Tredici, M.R. (2009) Microalgae for Oil: Strain Selection, Induction of Lipid Synthesis and Outdoor Mass Cultivation in a Low Cost Photobioreactor. Biotechnology and Bioengineering, 102, 100-112. http://dx.doi.org/10.1002/bit.22033 